\title{
HIGH DIAGNOSTIC EFFICIENCY OF IGM-ELISA WITH THE USE OF MULTIPLE ANTIGEN PEPTIDES (MAP1) FROM T. gondii ESA (SAG-1, GRA-1 AND GRA-7), IN ACUTE TOXOPLASMOSIS
}

Patrícia Regina Barboza ARAÚJO(1) \& Antonio Walter FERREIRA(1)

\begin{abstract}
SUMMARY
The main serological marker for the diagnosis of recent toxoplasmosis is the specific IgM antibody, along with IgG antibodies of low avidity. However, in some patients these antibodies may persist long after the acute/recent phase, contributing to misdiagnosis in suspected cases of toxoplasmosis. In the present study, the diagnostic efficiency of ELISA was evaluated, with the use of peptides derived from T. gondii ESA antigens, named SAG-1, GRA-1 and GRA-7. In the assay referred to, we studied each of these peptides individually, as well as in four different combinations, as Multiple Antigen Peptides (MAP), aiming to establish a reliable profile for the acute/recent toxoplasmosis with only one patient serum sample. The diagnostic performance of the assay using MAP1, with the combination of SAG-1, GRA-1 and GRA-7 peptides, demonstrated better discrimination of the acute/recent phase from non acute/ recent phase of toxoplasmosis. Our results show that IgM antibodies to MAP1 may be useful as a serological marker, enhancing the diagnostic efficiency of the assay for acute/recent phase of toxoplasmosis.
\end{abstract}

KEYWORDS: Toxoplasmosis; Serology; MAPs; ESA.

\section{INTRODUCTION}

Toxoplasmosis is a prevailing infection among humans and other warm-blooded animals, caused by an intracellular protozoa, Toxoplasma gondii. There is a significant danger to the fetuses of mothers who acquire the infection during pregnancy, and it has been established as a cause of life-threatening disease in immunocompromised individuals. The diagnosis of $T$. gondii infection is of considerable importance, because there are specific anti-T. gondii therapies. Serological diagnosis of acute Toxoplasmosis has traditionally been made by detection of specific IgM antibodies or by the demonstration of a significant increase in specific IgG antibody levels, or both. Because specific IgM antibodies can persist for several months, or even years in some individuals, following acute infection, interpretation of serological tests might be troublesome when acute Toxoplasmosis is suspected ${ }^{9}$. The diagnosis of chronic stage of infection or of past exposure to $T$. gondii is made by detection of specific IgG antibodies and the absence of the acute-phase markers $\operatorname{IgM}$ and $\operatorname{Ig} \mathrm{A}^{22}$. The currently available commercial tests to detect $\mathrm{IgG}$, $\operatorname{IgM}$ and $\operatorname{IgA}$ antibodies rely mostly on preparations of crude parasite antigens, i.e. with tachyzoites harvested from infected mice or cell cultures. However, the use of whole-tachyzoites antigens can result in false-positive reactions thereby reducing the clinical value based on serological data ${ }^{9,11,13,28}$. Tachyzoite antigens are obtained differently in respect to their source and process for their collection and purification. These facts imply that the reactivity among antigens may vary greatly, contributing to inaccurate provision of diagnostic efficiency by assay systems. Several reports $1,2,4,6,7,10,16,23,27,29$ have emphasized the value of the detection of specific antibodies raised to excreted-secreted antigens (ESA) of $T$. gondii for the diagnosis of acute toxoplasmosis. The $T$. gondii ESA constitutes $90 \%$ of the circulating antigens in infected humans, thus is one of the first targets of the host immune response $\mathrm{e}^{6}$

Recombinant antigens and synthetic peptides have been prepared from ESA antigens, however, the exact composition and association of recombinant antigens and peptides to be used in immunoassays to detect toxoplasma antibodies is still an open question. The identification of human immunodominant B-cell epitopes within the T. gondii antigens can help to find those antigens involved in the specicific B-cell response, and they will be useful for immunoassays to detect anti-toxoplasma antibodies ${ }^{15,25,28}$. TAM $^{32}$ described in 1988 a novel immunological approach, consisting of some immunodominant sequences of peptides associated by means of a small peptidyl core matrix (multiple Antigen Peptide - MAP). This association presents several advantages such as: the antigen composition of the test being precisely known, being able to use more than one defined antigens; immunogenicity, antigenicity and possibility for easy standardization of the method. So, multiple antigen peptides may be an alternative source of antigens that are characteristic of the acute or chronic stages of the infection, serving as a tool to discriminate the acute/recent toxoplasmosis from chronic stages. The design of MAP chosen for study by above authors consisted of a core

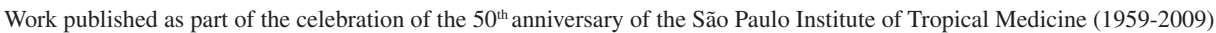

(1) Institute of Tropical Medicine of University of São Paulo, São Paulo, SP, Brazil.

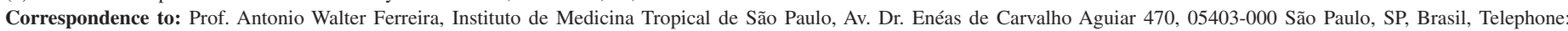
+55 113061 7022. E-mail: clawsmbf@usp.br 


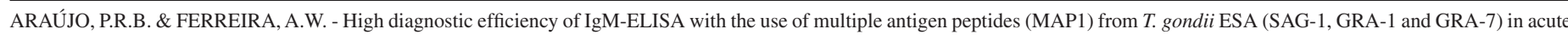
toxoplasmosis. Rev. Inst. Med. Trop. Sao Paulo, 52(2):63-8, 2010.

matrix with heptalysine containing three dendritic arms of $T$. gondii ESA peptides in length. The ESA peptides chosen were granule protein 1 GRA1) correlated with chronic toxoplasmosis, granule protein 7 (GRA-7) detected in acute toxoplasmosis ${ }^{16,22}$ and surface antigen 1 (SAG-1) present only in the tachyzoite stage and marker of acute toxoplasmosis ${ }^{2,7,26}$. In the present study, we evaluated the diagnostic efficiency of ELISA with the use of SAG1, GRA1 and GRA7 peptides derived from T. gondii ESA, individually and in combined forms as MAP, for the detection of $\mathrm{IgG}$, $\operatorname{IgM}$ and IgA antibodies, aiming to establish a profile of acute/recent toxoplasmosis, with a single serum sample.

\section{MATERIAL AND METHODS}

Serum samples. A total of 300 serum samples was obtained from individuals during routine screening for Toxoplasmosis and analyzed by a commercially available kit for ELISA (VIDAS BioMérieuxBrazil) and classic serological methods (indirect immunofluorescence assay (IFA) (BioMérieux-Brazil) and indirect hemagglutination assay (HAI) (BioMérieux-Brazil) to detect IgM and IgG antibodies, anti-T. gondii and avidity of specific IgG antibodies. Sera were selected as previously described by FERREIRA \& CAMARGO ${ }^{9}$; MONTOYA ${ }^{24}$ and PIETKIEWICZ et al. ${ }^{28}$, based on clinical and serological data. Five groups were studied according to the clinical and serological findings as follows. Group I comprised 25 patients, presenting clinical and serological symptoms compatible with acute or acute/recent toxoplasmosis. They exhibited specific IgM antibodies (titer $\geq 64$ ), IgG antibodies (titer $\leq 128$ ) by IFA and HAI, and low avidity of $T$. gondii-specific IgG. Serum samples were positive for $T$. gondii-specific IgG and IgM by automated ELISA assay. Group II had 25 patients, without clinical symptoms or serological profiles of non-acute/recent toxoplasmosis. They showed specific IgM antibodies (titer $\leq 64$ ), IgG antibodies (titer $\geq 28$ ) by IFA and HAI, and high avidity of $T$. gondii-specific IgG. Serum samples were positive for T. gondii-specific IgG and IgM by automated ELISA assay. Group III included 100 individuals, exhibiting specific IgG antibodies (titer $\geq 256$ ) by IFA and HAI, negative results for T. gondii-specific IgM by IFA and HAI, and high avidity of $T$. gondii-specific IgG. Serum samples were positive for IgG and negative for IgM T. gondii-specific by ELISA automated assay. No patient presented clinical symptoms, but, serological data was suggestive of past toxoplasmosis. Group IV consisted of 100 clinically healthy controls without present or previous serological data suggesting toxoplasmosis, i.e. neither IgM nor IgG antibodies were detected by IFA, HAI or ELISA automated assay. Group V had 50 patients with unrelated infections, but who had defined clinical and serological diagnosis of rubella (10), mononucleosis (10), cytomegalovirus (10), malaria (10) and Chagas disease (10). The ethical committee of the Institute of Tropical Medicine, University of São Paulo approved the project.

ESA. T. gondii T. gondii tachyzoites, RH strain, were obtained from the peritoneal cavity of Balb/c mice infected two days earlier and inoculated into culture of human fibroblast cells for three hours at $37^{\circ} \mathrm{C}$. The culture supernatants were centrifuged at $1000^{\mathrm{x}} \mathrm{g}$ for 10 minutes and filtered through $0.22-\mu \mathrm{m}$-pore-size membrane (Millipore Corporation, Bedford, Massachusetts). The ESA was stored at $-70{ }^{\circ} \mathrm{C}$ with $100 \mathrm{U} / \mathrm{mL}$ aprotinin (Sigma Chemical Co, St. Louis, Missouri).

Viability of tachyzoites and protein concentration. After washing three times with PBS pH 7.2, the culture of human fibroblasts was inoculated with $1 \times 10^{8}$ tachyzoites and incubated at $37^{\circ} \mathrm{C}$. Five-milliliter aliquots of culture were taken at various intervals from 1, 2, 3, 4, 5, 6, 12 and 24 hours post-infection. The number and viability of tachyzoites were evaluated in these aliquots by the Tripan blue method and the protein concentration was determined using the Bio-RAD DC Protein Assay (France).

PAGE. The ESA was eletrophoresed in polyacrylamide slab gel using a discontinuous sodium dodecyl sulfate (SDS) buffer system as described by $\mathrm{LAEMMLI}^{20}$, with an $18 \%$ running gel and $3 \%$ stacking gel. The running buffer contained $25 \mathrm{mM}$ TRIS, $192 \mathrm{mM}$ glycine, and $0.1 \%$ SDS at $\mathrm{pH}$ 8.3. Gels were run at 5-6 V/cm until the bromophenol blue marker reached the bottom. Molecular weight markers (Full Range RainbowTM, Amersham Life Sciences, UK) were used to plot the calibration curve. Proteins were transferred from SDS slab gel to a polyvinyllidene difluoride membrane (Immobilon PVDF, Millipore, USA).

Synthesis of SAG-1, GRA-1 and GRA-7 peptides. The SAG-1, GRA-1 and GRA-7 peptides were synthesized from PVDF membrane obtained after T. gondii ESA proteins eletrophoresed as above on Tentagel S resin (Rapp Polymere GmbH, Tubingen, Germany) by using a Rainin Symphony Multiplex synthesizer (Protein Technology, Tucson, Arizona) with standard 9-7 fluorenylmethoxycarbonyl (Fmoc) chemistry. Standard double couplings were performed by using a fourfold excess of Fmoc-protected amino acids active in situ with equimolar amounts of N-hydroxybenzotriazole and 2-(1 H-benzotriazole-1-yl)-1,1,3,3tertamethyluronium tertafluoroborate twice for 20 minutes each time. The Fmoc protecting group was removed by using a mild base treatment with $2 \%$ piperidine 1,8-diazabicyclo[5.4.0] undec-7-ene (DBU) in dimethyl sulfoxide- $70 \%$ domethylformamide with in situ activation. The peptide sequence chosen for SAG-1 is based in KATO et al. ${ }^{19}$; for GRA-1 in BEGHETTO et al. ${ }^{3}$; and for GRA-7 in SOUSA et al. ${ }^{31}$.

MAP: Combination of SAG-1, GRA-1 and GRA-7 peptides. After the synthesis completion, the peptide was cleaved from the resin by incubation for 2.5 hours with $90 \%$ trifluoroacetic acid-5\% thioanisole-3\% ethanedithiol- $2 \%$ anisole. The peptide was precipitated from the mixture by using $t$-butyl methyl ether. After centrifugation, the pellet was washed three times with t-butyl methyl ether and dried overnight in a vacuum $\left(\mathrm{TAM}^{32}\right)$. The purity of the crude peptide was checked by reverse-phase high-performance liquid chromatography, lyophilized, and stored at $4{ }^{\circ} \mathrm{C}$ until use.

ELISA with individual peptides (SAG-1, GRA-1 and GRA-7). Microtiter plate (Immuno Plate Maxisorp; Nunc) wells were coated overnight at room temperature with $50 \mu \mathrm{L}$ of each of the peptides SAG-1, GRA-1 or GRA-7 diluted in $0.05 \mathrm{M}$ carbonate buffer (pH 9.6) at the optimal concentration of $10 \mu \mathrm{g} / \mathrm{mL}$ determined by block titration. After coating, the wells were washed three times with PBS/0.25\% Tween 20 (PBS-T) and blocked with $200 \mathrm{~mL}$ of $5 \%$ skim milk in PBS-T (blocking solution) for two hours at $37^{\circ} \mathrm{C}$. The plates were then washed as described above and $100 \mu \mathrm{L}$ of test or control serum were applied to each well. To test for IgG, the sera were diluted 1:100 in blocking solution. In the case of $\operatorname{IgM}$ or $\operatorname{IgA}$ detection, the sera were diluted at the optimal 1:25 in blocking solution, as determined by previous block titration. The plates were incubated for two hours at room temperature and washed as described above. Goat antihuman IgG, IgM, or IgA peroxidase-labeled antibodies (Sigma Chemical Co., St Louis, Missouri) diluted 1:200 were used as the secondary antibody. After being incubated for one hour at room temperature and washings, 


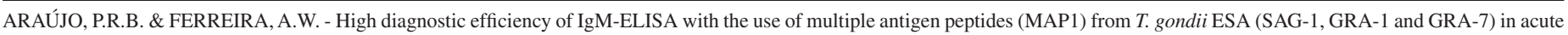
toxoplasmosis. Rev. Inst. Med. Trop. Sao Paulo, 52(2):63-8, 2010.

immune complexes were developed with ortho-phenylenediamine as the chromogenic substrate. Ate reactivity was measured at $490 \mathrm{~nm}$ in an automatic enzyme-linked immunosorbent assay (ELISA) reader (Reader 230S-Anthos). Each serum was assayed in duplicate by ELISA. For each peptide the cut-off level was determined according to the mean value of optical density (plus three standard deviations) of the negative controls.

ELISA with MAPs. Each microtiter plate well (Immuno Plate Maxisorp; Nunc) was coated overnight at room temperature with 100 $\mu \mathrm{L}$ of the MAP1, MAP2, MAP3 or MAP4 diluted in $0.05 \mathrm{M}$ carbonate buffer ( $\mathrm{pH}$ 9.6) at the optimal concentration of $5 \mu \mathrm{g} / \mathrm{mL}$ found by block titration. After coating, the wells were washed three times with PBS $/ 0.25 \%$ Tween 20 (PBS-T) and blocked with $200 \mathrm{~mL}$ of $5 \%$ skim milk in PBS-T (blocking solution) for two hours at $37{ }^{\circ} \mathrm{C}$. The plates were then washed as described above and $100 \mu \mathrm{L}$ of test or control serum were applied to each well. For the detection of IgG to MAP1, MAP2, MAP3 or MAP4, sera were diluted 1:200 in blocking solution. To detect IgM and IgA to MAP1, MAP2, MAP3 or MAP4, sera were diluted at 1:50 in blocking solution, as determined by block titration. The plates were incubated for two hours at room temperature and washed as described above. Goat anti-human $\operatorname{IgG}$, IgM, or IgA peroxidase-labeled antibodies (Sigma Chemical Co., St Louis, Missouri) diluted 1:200 were used as the secondary antibody. After being incubated for one hour at room temperature and washings performed, immune complexes were developed with ortho-phenylenediamine as the chromogenic substrate. The reactivity was measured at $490 \mathrm{~nm}$ in an automatic enzyme-linked immunosorbent assay (ELISA) reader (Reader 230S- Anthos). Each serum was assayed in duplicate by ELISA. For each MAP the cut-off level was determined according to the mean value of optical density (plus three standard deviations) of the negative controls.

Diagnostic performance of ELISA using different peptides. The diagnostic parameters were defined in terms of sensitivity, specificity and efficiency, according to FERREIRA \& AVILA (2001) ${ }^{8}$. The sensitivity was determined independently for groups I9(25), II(25) and III(100): (ELISA positive)/(Positive by conventional reference data). The specificity was calculated with the sum of results obtained from control groups IV(100) and V(50): (ELISA negative)/(Negative by reference data). For the diagnostic efficiency, in turn, the calculation was as follows: (ELISA positive + ELISA negative)/(Positive by reference data + Negative by reference data). The reference data corresponds to the aforementioned conventional clinical and serological findings.

\section{RESULTS}

A total of 300 serum samples belonging to five groups of patients was studied by ELISA, using each of three peptides independently and also in their four different combinations.

Reactivities of IgG, IgM and IgA antibodies with SAG-1, GRA-1 and GRA-7 peptides. As shown in Table 1, IgG, IgM and IgA antibodies' reaction to SAG-1, GRA-1 and GRA-7 were found in patients from group I, II and III. In terms of sensitivity, the IgG-ELISA using individually three different peptides varied from $98 \%$ to $68 \%$. In the IgM-ELISA with the use of same peptides, the sensitivity varied from $88 \%$ to $5 \%$. In the IgA-ELISA antibodies to these three peptides were observed in patients from group I and II, ranging from $92 \%$ to $12 \%$. However in the group III, IgA antibodies were detected by the use of these antigens. In groups IV
Table 1

Sensitivity of IgG-, IgM- and IgA-ELISA with the use of SAG-1, GRA-1 and GRA-7 peptides and with their four different combinations as MAP1, 2, 3 and 4 for the diagnosis of human toxoplasmosis

\begin{tabular}{lllll}
\hline $\begin{array}{l}\text { Antibodies to } \\
\text { Peptide }(\mathrm{S})\end{array}$ & $\begin{array}{l}\text { Group I } \\
\% \text { Sensitivity }\end{array}$ & $\begin{array}{l}\text { Group II } \\
\text { \% Sensitivity }\end{array}$ & $\begin{array}{l}\text { Group III } \\
\% \text { Sensitivity }\end{array}$ \\
\hline IgG to: & & & & \\
& SAG-1 & $88(22 / 25)$ & $84(21 / 25)$ & $98(98 / 100)$ \\
& GRA-1 & $76(19 / 25)$ & $68(17 / 25)$ & $97(97 / 100)$ \\
& GRA-7 & $84(21 / 25)$ & $76(19 / 25)$ & $94(94 / 100)$ \\
& MAP1 & $100(25 / 25)$ & $100(25 / 25)$ & $100(100 / 100)$ \\
& MAP2 & $0(0 / 25)$ & $0(0 / 25)$ & $0(0 / 25)$ \\
MAP3 & $0(0 / 25)$ & $0(0 / 25)$ & $0(0 / 25)$ \\
MAP4 & $0(0 / 25)$ & $0(0 / 25)$ & $0(0 / 25)$ \\
\hline IgM to: & & & & \\
& SAG-1 & $88(22 / 25)$ & $16(4 / 25)$ & $5(5 / 100)$ \\
GRA-1 & $52(13 / 25)$ & $44(11 / 25)$ & $13(13 / 100)$ \\
GRA-7 & $88(22 / 25)$ & $24(6 / 25)$ & $6(6 / 100)$ \\
MAP1 & $100(25 / 25)$ & $0(0 / 25)$ & $0(0 / 100)$ \\
MAP2 & $0(0 / 25)$ & - & - \\
MAP3 & $0(0 / 25)$ & - & - \\
MAP4 & $0(0 / 25)$ & - & - \\
\hline IgA to: & & & & $0(0 / 100)$ \\
SAG-1 & $92(23 / 25)$ & $12(3 / 25)$ & $0(0 / 100)$ \\
GRA-1 & $84(21 / 25)$ & $48(12 / 25)$ & $0(0 / 100)$ \\
GRA-7 & $84(21 / 25)$ & $16(4 / 25)$ & $0(0 / 100)$ \\
MAP1 & $96(24 / 25)$ & $92(23 / 25)$ & - \\
MAP2 & $0(0 / 25)$ & - & - \\
MAP3 & $0(0 / 25)$ & - & - \\
MAP4 & $0(0 / 25)$ & - & \\
\hline
\end{tabular}

and $\mathrm{V}$, specific IgG, IgM or IgA antibodies to SAG-1, GRA-1 or GRA-7 peptides were not observed, indicating the absence of cross-reactivity by the assay. It is worth mentioning the cut-off values determined for the detection of specific antibodies. In the detection of IgG antibodies to different peptide antigens as isolate or associate forms, considering five patient groups, cut-offs varied from 0.258 to 0.421 , while for the detection of IgM antibodies, cut-offs ranged from 0.145 to 0.188 , and for IgA antibodies, from 0.111 to 0.127 . The overall data demonstrates that reactivities of $\operatorname{IgG}, \operatorname{IgM}$ and $\operatorname{Ig}$ A antibodies with SAG-1 were higher in patients from group I of acute/recent toxoplasmosis than other groups. However in group II and III, only IgG antibodies were highly reactive with the same peptide.

Reactivities of IgG, IgM and IgA antibodies with the combination of peptides MAP1, MAP2, MAP3 and MAP4 by ELISA. All sera from patients with acute/recent toxoplasmosis (group I), anti-MAP1 (SAG-1, GRA-1 and GRA-7) were detected. Figure 1 shows that IgG antibodies from all $25(100 \%)$ patients reacted with MAP1, and their positive values were far from the stipulated value of cut-off (0.258). In other words, the mean value of the 25 sera was 3.2 , with standard deviation (SD) of 0.014 . In addition, these $25(100 \%)$ sera reacted with MAP1 by IgM-ELISA. The mean value found for these sera was 3.8 (SD 0.012). In respect to IgA-ELISA, 96\% (24/25) sera were positive and their mean value was 3.5 (SD 0.013). All 25 sera from patients with non-acute/recent toxoplasmosis (group II) as shown in Figure 1, had IgG antibodies and 
ARAÚJO, P.R.B. \& FERREIRA, A.W. - High diagnostic efficiency of IgM-ELISA with the use of multiple antigen peptides (MAP1) from T. gondii ESA (SAG-1, GRA-1 and GRA-7) in acute toxoplasmosis. Rev. Inst. Med. Trop. Sao Paulo, 52(2):63-8, 2010.

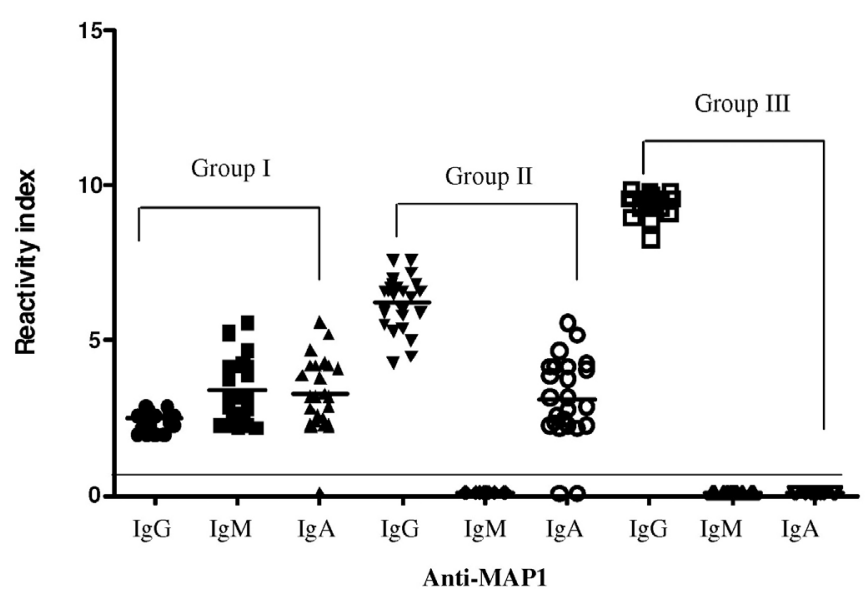

Fig. 1 - Reactivity of IgG, IgM and IgA antibodies with MAP1 (SAG-1, GRA-1 and GRA-7) peptides, in the study of serum samples from group I, including patients with acute/recent toxoplasmosis, group II with non-acute/recent toxoplasmosis and group III with chronic toxoplasmosis, by ELISA.

their values were far above the cut-off level. The mean value of the 25 sera was 6.8 (SD 0.016). In this group, these 25 sera did not react with MAP1 by IgM-ELISA. The mean value of the 25 sera was 0.4 (SD 0.018). On the other hand, 23/25 sera (92\%) showed IgA reactivity against MAP1. The mean value of the 23 sera was 2.6 (SD 0.014). In all 100 sera from patients with chronic toxoplasmosis (group III), IgG antibodies reacted strongly with MAP1, and none of the positive results were close to the cut-off value. Their mean value was 9.2 (SD 0.016). In contrast, this group had no $\operatorname{IgM}$ and $\operatorname{IgA}$ antibodies reacting with MAP1. In control groups IV and V, there were no anti-MAP1 IgG, IgM and $\operatorname{IgA}$, i.e., no cross-reactivity was observed in these groups (Fig. 2). As for the IgGELISA using MAP2, MAP3 and MAP4, antibodies were not detected in any sera from groups I, II and III. The IgM-ELISA and IgA-ELISA did not detect antibodies to same antigens in any sera from group I. On the other hand, in sera from groups II and III, IgM and IgA antibodies to MAP2, MAP3 and MAP4 were found. In respect to groups IV and V, IgG, IgM and IgA antibodies were not seen, showing no cross-reactivity in any of the serum samples. Thus, it can be stressed that a maximum

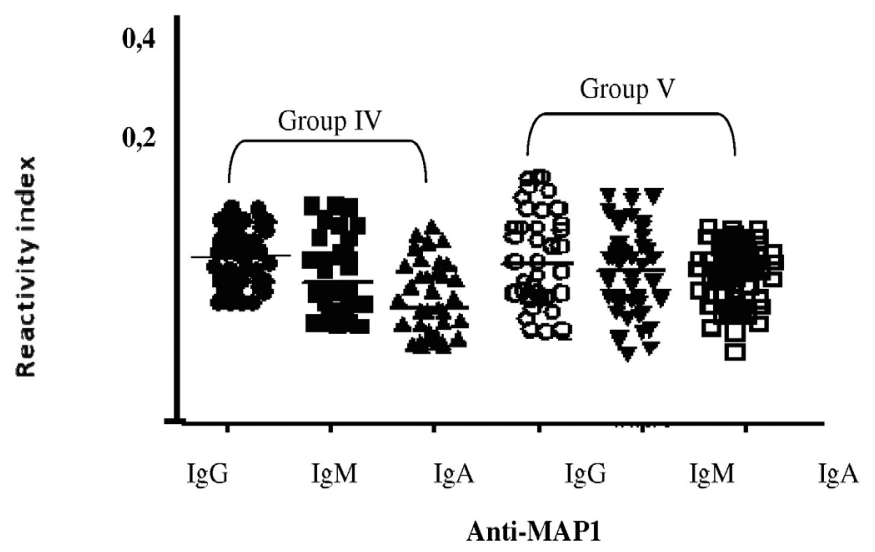

Fig. 2 - Reactivity of IgG, IgM and IgA with MAP1 (SAG-1, GRA-1, GRA-7) peptides, by ELISA, in the study of serum samples of group IV, consisting of clinically healthy individuals, and group $\mathrm{V}$, with unrelated pathologies. efficiency was observed by IgM-ELISA utilizing MAP1 antigen for the diagnosis of acute/recent toxoplasmosis.

\section{DISCUSSION}

A century has elapsed since the early studies of Sabin and Feldman about the diagnosis of Toxoplasmosis. Traditional manual laboratory methods, adequate for small routines, have been replaced with automated or semi-automated procedures involving little manipulation and risk of human error. These systems can be used for large routine volumes at a reasonable price. In addition, continuous scientific and technical evolution has led to decisive progress in diagnosis through the search of gold standard tests that will provide safe information about the real health status of the patient. For years, the serological profile defined by experienced investigators has been accepted in laboratory diagnostic routine. However, current laboratory practice using highly sensitive automated equipment has led to problems with the detection of parasite specific $\operatorname{IgG}$ and $\operatorname{IgM}$ antibodies ${ }^{12,33}$. Several authors have shown that IgM to T. gondii can be detected for a long period after the primary infection and false positivities with $\operatorname{IgG}$ to $T$. gondii have been reported which are non-significant and erroneously interpreted as positive results indicating acute infection and protection ${ }^{19}$. Research and development have continued to advance and new parameters have been developed for the diagnosis of toxoplasmosis in its different phases, such as the avidity test of $\operatorname{IgG}$ antibodies and detection of the parasite by a molecular method such as polymerase chain reaction (PCR). The IgG avidity determination is an important serological marker that can be used to distinguish between acute/recent and non-acute phase, from a single serum sample. However, low $\operatorname{IgG}$ avidity results may persist for as long as one year after the primary infection because of immunosuppressive conditions or anti-toxoplasma pharmacotherapy that may affect the kinetics of the IgG avidity maturation ${ }^{5,11,13,20,23}$. The PCR has been successfully used in immunocompromised patients, ocular toxoplasmosis and congenital toxoplasmosis. However, some problems can be observed in laboratory practice, such as false negative results after treatment with anti-toxoplasma drugs, low and focal distribution of parasites in the tissues or the presence of non-viable parasites in autolyzed tissue. Excreted and secreted antigen (ESA) of $T$. gondii has been used in detection of specific antibodies for the diagnosis of acute toxoplasmosis ${ }^{1,2,3,4,6,7,15,27}$. As previously mentioned, circulating antigens in infected humans are constituted by $T$. gondii ESA, and are one of the first targets of the host immune response ${ }^{26}$. In addition, the ESA plays a role in the persistent stimulation of cellmediated immunity in chronically infected healthy subjects. Several fractions from $T$. gondii ESA isolated or in combination have been used in the diagnosis of toxoplasmosis. Among the fractions of $T$. gondii ESA, surface antigen 1 (SAG-1) has been extensively studied. SAG-1 is the most immunodominant and stage-specific antigen present in tachyzoite stage and not in bradyzoite stage. SAG-1 is one of the first antigens recognized by IgM antibodies during acute/recent phase. However, as confirmed here with our previous ${ }^{2}$ data and that of others ${ }^{7,26}$, specific anti-SAG-1 antibodies can be detected in chronic toxoplasmosis and non-acute/recent phase. Other important ESA fractions used in various studies for the diagnosis of toxoplasmosis originate from granule-dense organelles (GRA-7). This antigen produces a strong antibody response in the acute phase of infection and is found in the parasitophorous vacuole and the cytoplasm of the tachyzoite-infected host cell, leading to immune recognition due to constant rupture of the 


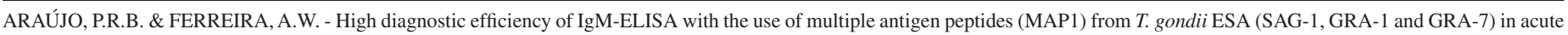
toxoplasmosis. Rev. Inst. Med. Trop. Sao Paulo, 52(2):63-8, 2010.

cyst cells ${ }^{16}$. The granule-dense 1 antigen (GRA-1) reacts strongly with serum samples from pregnant women infected with $T$. gondii ${ }^{3}$ and, as we found here, with sera from chronic and acute/recent toxoplasmosis, as in reported ${ }^{16}$ data. The present study was undertaken since the exact composition and conformation of T. gondii ESA antigens to be used to detect $\operatorname{IgG}$ and $\operatorname{IgM}$ antibodies in an immunoassay remained an open question. The assay performance varies significantly due to the influence of factors such as the number of serological targets to be sequestered within internal organelles, as well as the method utilized for the parasite antigen preparation. Advances in molecular biology permitted the obtainment of purified antigens, being an attractive alternative to improving the sensitivity and specificity of serological tests, in particular, for the detection of IgM antibodies. In this context, the multimeric nature of the MAP constructs provides reproducible results and increased surface binding. MAPs may also improve the early detection of antibodies of low affinity, such as those of the $\operatorname{IgM}$ isotype, during the early phase of infections. Significant advances by many laboratories have led to applications of MAPs for serodiagnosis. MAP showed a sensitivity increase of $>10^{8}$-fold compared with peptide antigen in an enzyme-linked immunosorbent assay (ELISA) ${ }^{28}$. These results indicate that MAPs may be antigens of choice for solid phase based immunoassays and they also are a promising tool for serodiagnosis in naturally immunized or infected individuals ${ }^{28}$. In a recent study, NOYA et al. ${ }^{27}$ compared various antigenic preparations with MAP for the diagnosis of different infections and reported high sensitivity and specificity of assays at low cost.

In this work, we evaluated the diagnostic efficiency of $\mathrm{IgG}$, IgM- and IgA-ELISA, using a combination of SAG-1, GRA-1 and GRA-7 constructed by the MAP system, to establish a profile of acute toxoplasmosis in single serum samples. In other words, we searched for a serologic marker among IgG, IgM and IgA antibodies by the use of MAP1 peptides, and conferring on ELISA maximum diagnostic efficiency. We already mentioned that the SAG-1, GRA-1 and GRA-7 in individual analysis and the sensitivity of the IgG-, IgM- and IgA-ELISA was low, due to the false negative results observed in the study of group of patients I, II and III (Table 1). In addition, positivity observed in these same groups of patients, by means of the above referred to assays, did not permit discrimination of acute/recent toxoplasmosis from other phases of the infection (Table 1). The IgG-ELISA using independently the peptides GRA-1 and GRA-7, although showing good sensitivities for chronic toxoplasmosis, cannot be helpful as confirmatory assays, as referred to JACOBS et al.(1999) ${ }^{17}$ and BEGHETTO et al. (2001) ${ }^{3}$. Maximum specificity was observed in the control groups (IV and V) including clinically healthy individuals and others with unrelated pathologies. After the study of each fraction, we dealt with different peptide combinations: MAP1 (SAG-1, GRA-7 and GRA-1); MAP2 (SAG-1 and GRA-1); MAP3 (SAG-1 and GRA-7) and MAP4 (GRA-1 and GRA-7) to see their ability to react with $\operatorname{IgG}, \operatorname{IgM}$ and $\operatorname{IgA}$ T. gondii by ELISA. In the initial evaluation of the different peptide combinations by the assay, we observed that when SAG-1 was present, as in the MAP1, the sensitivity and specificity in the detection of $\operatorname{IgG}, \operatorname{IgM}$ and $\operatorname{IgA}$ antibodies in different toxoplasmosis phases was higher compared with those without SAG-1, as MAP4 (Table 1). Our results are consistent with the results of other investigators who have found that SAG-1 improves the sensitivity and specificity of serological assays ${ }^{19,25}$. In the study of other peptide combinations such as, MAP2, 3 and 4, the assay presented low diagnostic performance, and the acute/recent, non-acute/recent and chronic phase could not be distinguished as in the assay using MAP1. These results indicate that different proportions of SAG-1 peptides found in the ESA T. gondii will influence greatly the diagnosis features of the assay, in the routine diagnosis of acute/recent toxoplasmosis.

We analyzed the diagnostic efficiency of ELISA using MAP1 peptides for the detecting of $\operatorname{IgG}, \operatorname{IgM}$ and $\operatorname{IgA}$ antibodies in three different groups and we found an increase of the assay sensitivity, mainly in the detection of $\operatorname{IgM}$ antibodies. Therefore, the sensitivity and the specificity of IgM-ELISA for acute/recent toxoplasmosis were maximum (100\%) and, consequently, its diagnostic efficiency. In contrast, the non-acute/recent toxoplasmosis group, in spite of presenting some residual IgM antibodies detectable by a commercial kit, IgM antibodies to MAP1 were demonstrated. NOYA et al. ${ }^{27}$ investigated the use of MAP in an assay for the diagnosis of unrelated pathologies and they found similar specificity and sensitivity as we did with MAP1. In study of PIETKIEWICZ et al. ${ }^{28}$ using recombinant (SAG-1, GRA-1 and GRA-7) antigens, the acute/recent and non-acute/recent phase of toxoplasmosis could not be discriminated. Our results indicate that MAP1 may be the antigen of choice for the use in solid phase based immunoassays and these are promising tools for the serodiagnosis of acute/recent toxoplasmosis. The combination of SAG-1, GRA-1 and GRA-7 peptides, derived from ESA T. gondii, as MAP1 system will be helpful in the laboratory practice to distinguish acute/recent from non-acute/recent toxoplasmosis, with a single serum sample.

\section{RESUMO}

\section{Alta eficiência diagnóstica do IgM ELISA com o uso de múltiplos antígenos peptídicos (MAP1) de T. gondii ESA (SAG-1, GRA-1 e GRA-7) na toxoplasmose aguda}

O principal marcador sorológico para o diagnóstico da toxoplasmose aguda ou recente são os anticorpos IgM específicos, a par de anticorpos IgG de baixa avidez. Entretanto em alguns pacientes, estes anticorpos podem persistir, ultrapassando o período da fase aguda/recente, contribuindo para erro diagnóstico em casos suspeitos de toxoplasmose. No presente estudo, a eficiência diagnóstica de ELISA foi avaliada, com o uso de frações ou peptídeos originados dos antígenos ESA de $T$. gondii, denominados de SAG-1, GRA-1 e GRA-7. No referido ensaio, estudamos cada uma destas frações isoladamente, como também em quatro diferentes combinações, ou múltiplos peptídeos antigênicos (MAP), visando estabelecer um perfil confiável para a toxoplasmose aguda/recente em amostra única de soro. A melhor eficiência diagnóstica do ensaio foi encontrada com o uso da combinação de peptídeos SAG-1, GRA-1 e GRA-7, denominada MAP1. A detecção de anticorpos IgG e IgM anti-MAP-1 apresentou melhores características diagnósticas para a diferenciação entre a fase aguda/recente da fase não aguda/recente na toxoplasmose. Nossos resultados mostram que anticorpos $\operatorname{IgM}$ anti-MAP-1 poderão prestar auxílio como um marcador sorológico, aumentando a eficiência diagnóstica do ensaio para a fase aguda/recente da toxoplasmose.

\section{REFERENCES}

1. Acebes MV, Diez B, Garcia-Rodrigues JA, Viens P, Cisterna R. Detection of circulating antigens in the diagnosis of acute toxoplasmosis. Am J Trop Med Hyg. 1994;51:50611 . 
ARAÚJO, P.R.B. \& FERREIRA, A.W. - High diagnostic efficiency of IgM-ELISA with the use of multiple antigen peptides (MAP1) from T. gondii ESA (SAG-1, GRA-1 and GRA-7) in acute toxoplasmosis. Rev. Inst. Med. Trop. Sao Paulo, 52(2):63-8, 2010.

2. Araújo PR, Ferreira AW. Avidity of IgG antibodies against excreted/secreted antigens of Toxoplasma gondii: immunological marker for acute recent toxoplasmosis. Rev Soc Bras Med Trop. 2008;41:142-7.

3. Beghetto E, Pucci A, Minenkova O, Spadoni A, Bruno L, Buffolano W, et al. Identification of a human immunodominant B-cell epitope within the GRA1 antigen of Toxoplasma gondii by phage display of cDNA libraries. Int J Parasitol. 2001;31:165968.

4. Bessières MH, Le Breton S, Séguéla JP. Analysis by immunoblotting of Toxoplasma gondii exo-antigens and comparison with somatic antigens. Parasitol Res. 1992; 78:222-8.

5. Camargo ME, Silva SM, Leser PG, Granato CH. Avidez de anticorpos IgG específificos com marcadores de infecção primária recente pelo Toxoplasma gondii. Rev Inst Med Trop Sao Paulo. 1991;33:213-8.

6. Cesbron-Delauw MF, Capron A. Excreted/secreted antigens of Toxoplasma gondii - their origin and role in the host-parasite interaction. Res Immunol. 1993;144:41-2.

7. Decoster A, Darcy F, Capron A. Recognition of Toxoplasma gondii excreted and secreted antigens by human sera from acquired and congenital toxoplasmosis: identification of markers of acute and chronic infection. Clin Exp Immunol. $1988 ; 73: 376-82$

8. Ferreira AW, Avila SLM. Diagnóstico laboratorial. Avaliação de métodos de diagnóstico das principais doenças infecciosas e parasitárias e auto-imunes. Correlação clínico-laboratorial. 2a ed. Rio de Janeiro: Guanabara Koogan; 2001.

9. Ferreira AW, Camargo ME. Toxoplasmosis and the laboratory: diagnosis and a constant striving for improvement. Rev Inst Med Trop Sao Paulo. 2002;44:119-20.

10. Fischer HG, Stachelhaus S, Sahm M, Meyer HE, Reichmann G. GRA7, an excretory $29 \mathrm{kDa}$ Toxoplasma gondii dense granule antigen released by infected host cells. Molec Biochem Parasitol. 1998;91:251-62.

11. Hafid J, Tran MSR, Raberin H, Akono ZY, Pozzetto B, Jana M. Detection of circulating antigens of Toxoplasma gondii in human infection. Am J Trop Med Hyg. 1995; 52:336-9.

12. Hedman K, Lappalainen M, Seppaia I, Makela O. Recent primary toxoplasma infection indicated by a low avidity of specific IgG. J Infect Dis. 1989;159:736-40.

13. Hofgartner WT, Swanzy S, Bacina RM, Condon J, Gupta M, Maltlock PE, et al. Detection of immunoglobulin G (IgG) and IgM antibodies to Toxoplasma gondii: evalution of four commercial immunoassay systems. J Clin Microbiol. 1997;35:3313-5.

14. Holliman RE, Raymond R, Renton N, Johnson JD. The diagnostic of toxoplasmosis using IgG avidity. Epidemiol Infect. 1994;112:399-408.

15. Hughes HP, Hudson L, Fleck DG. In vitro culture of Toxoplasma gondii in primary and established cell lines. Int J Parasitol. 1986;16:317-22.

16. Hughes HPA, Van Knapen F. Characterization of a secretory antigen from Toxoplasma gondii and its role in circulating antigen production. Int J Parasitol. 1981;12:433-7.

17. Jacobs D, Vercammen M, Saman E. Evaluation of recombinant dense granule antigen 7 (GRA7) of Toxoplasma gondii for detection of immunoglobulin G antibodies and analysis of a major antigenic domain. Clin Diagn Lab Immunol. 1999;6:24-9.

18. Johnson LL, Berggren KN, Szaba FM, Chen W, Smiley ST. Fibrin-mediated protection against infection-stimulated immunopathology. J Exp Med. 2003;197:801-6.
19. Kato M, Claveria FG, Maki Y, Sanda K, Tanaka T, Omata Y, et al. Reactivity synthetic SAG1 (p30) peptide sequences with RH, S273 and Beverley strain induced antiToxoplasma gondii antibodies. Pathobiology. 2007;74:50-6.

20. Laemmli UK. Cleavage of structural proteins during the assembly of the head of bacteriophage T4. Nature. 1970;227(5259):680-5

21. Liesenfeld O, Montoya JG, Kinney S, Press C, Remington JS. Effect of testing IgC avidity in the diagnosis of Toxoplasma gondii infection in pregnant women: experience in a US reference laboratory. J Infect Dis. 2001;183:1248-53.

22. Marcolino PT, Silva DA, Leser PG, Camargo ME, Mineo JR. Molecular markers in acute and chronic phases of human toxoplasmosis: determination of immunoglobulin G avidity by Western blotting. Clin Diagn Lab Immunol. 2000;7:384-9.

23. Meek B, Diepersloot RJ, Van Gool T, Speijer D, Peek R. IgM recognition of recombinant Toxoplasma gondii antigens by sera of acutely or latently infected humans. Diagn Microbiol Infect Dis. 2003;45:45-52.

24. Montoya JG. Laboratory diagnosis of Toxoplasma gondii infection and toxoplasmosis J Infect Dis. 2002;185(suppl 1):S73-S82.

25. Montoya JG, Huffman HB, Remington JG. Evaluation of the immunoglobulin $\mathrm{G}$ avidity test for diagnosis of toxoplasmic lymphadenopathy. J Clin Microbiol. 2004;42:4627-31.

26. Montoya JG, Liesenfeld O. Toxoplasmosis. Lancet. 2004;363(9425):1965-76.

27. Noya O, Losada S, Toledo M, Alarcón de Noya B. The multiple antigen blot assay: a simple, versatile and multipurpose immunoenzymatic technique. Methods Mol Biol. 2009;536:237-51.

28. Pietkiewicz H, Hiszczyńska-Sawicka E, Kur J, Petersen E, Nielsen HV, Stankiewicz M et al. Usefulness of Toxoplasma gondii-specific recombinant antigens in serodiagnosis of human toxoplasmosis. J Clin Microbiol. 2004;42:1779-81.

29. Potasman I, Araujo FG, Desmonts G, Remington JS. Analysis of Toxoplasma gondii antigens recognized by human sera obtained before and after acute infection. J Infect Dis. $1986 ; 154: 650-7$

30. Prigione I, Facchetti P, Lecordier L, Deslee D, Chiesa S, Cesbron-Delauw MF et al. $\mathrm{T}$ cell clones raised from chronically infected healthy humans by stimulation with Toxoplasma gondii excretory-secretory antigens cross-react with live tachyzoites: characterization of the fine antigenic specificity of the clones and implications for vaccine development. J Immunol. 2000;164:3741-8.

31. Sousa S, Ajzenberq D, Marle M, Aubert D, Vilena I, Da Costa JC et al. Selection of polymorphic peptides from gra6 and gra7 sequences of Toxoplasma gondii strains to be used in serotyping. Clin Vaccine Immunol. 2009;16:1158-69.

32. Tam JP. Recent advances in multiple antigen peptides. J Immunol Methods 1996;196:17-32.

33. Velmurugan GV, Tewari AK, Rao JR, Baidya S, Kumar MU, Mishra AK. High-level expression of SAG-1 and GRA-7 gene of Toxoplasma gondii (lzatnagar isolate) and their application in serodiagnosis of goat toxoplasmosis. Vet Parasitol. 2008;154:18592.

Received: 3 November 2009

Accepted: 18 February 2010 